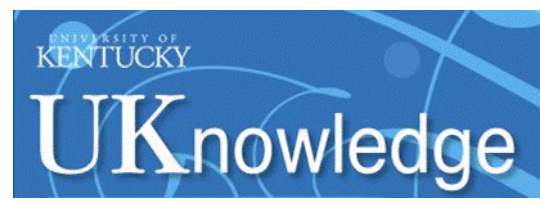

University of Kentucky

UKnowledge

$11-1996$

\title{
Effect of Sediment Particle Size and Temperature on Fecal Bacteria Mortality Rates and the Fecal Coliform/Fecal Streptococci Ratio
}

\author{
J. M. Howell \\ University of Kentucky \\ Mark S. Coyne \\ University of Kentucky, mark.coyne@uky.edu \\ P. L. Cornelius \\ University of Kentucky
}

Follow this and additional works at: https://uknowledge.uky.edu/pss_facpub

Part of the Environmental Microbiology and Microbial Ecology Commons, and the Plant Sciences Commons

Right click to open a feedback form in a new tab to let us know how this document benefits you.

\section{Repository Citation}

Howell, J. M.; Coyne, Mark S.; and Cornelius, P. L., "Effect of Sediment Particle Size and Temperature on Fecal Bacteria Mortality Rates and the Fecal Coliform/Fecal Streptococci Ratio" (1996). Plant and Soil Sciences Faculty Publications. 12.

https://uknowledge.uky.edu/pss_facpub/12

This Article is brought to you for free and open access by the Plant and Soil Sciences at UKnowledge. It has been accepted for inclusion in Plant and Soil Sciences Faculty Publications by an authorized administrator of UKnowledge. For more information, please contact UKnowledge@lsv.uky.edu. 
Effect of Sediment Particle Size and Temperature on Fecal Bacteria Mortality Rates and the Fecal Coliform/Fecal Streptococci Ratio

Digital Object Identifier (DOI)

http://dx.doi.org/10.2134/jeq1996.00472425002500060007x

Notes/Citation Information

Published in Journal of Environmental Quality, v. 25, no. 6, p. 1216-1220.

The copyright holder has granted the permission for posting the article here. 


\title{
Effect of Sediment Particle Size and Temperature on Fecal Bacteria Mortality Rates and the Fecal Coliform/Fecal Streptococci Ratio
}

\author{
J. M. Howell, M. S. Coyne,* and P. L. Cornelius
}

\begin{abstract}
Extended survival of fecal bacteria in sediment can obscure the source and extent of fecal contamination in agricultural settings. The variability in fecal coliform/fecal streptococci (FC/FS) ratios with time and discrepancies between observable fecal sources and measured FC/ FS ratios in shallow surface water from agricultural watersheds may be explained by examining FC and FS mortality rates in response to ambient temperature and sediment particle size. We measured FC and FS mortality rates at three different temperatures and in three feces-amended sediments with different particle size in a laboratory study. In controlled conditions, using physiological saline to reduce cell death by osmotic shock, FC mortality rates exceeded FS mortality rates. These rates declined as sediment particle-size shrank and as temperature decreased. There was no interaction between these two factors in determining fecal bacteria persistence. The apparent halflives of FCs exceeded those of FS, even though mortality rates were higher, because of $\mathrm{FC}$ regrowth shortly after deposition. The FC/FS ratio is influenced by temperature, the presence of sediment, and sediment particle size. In warm conditions, FC regrowth increases FC/FS ratios to levels indicative of human contamination even where none clearly exists. These factors interfere with the interpretation of the FC/FS ratio and contribute to the difficulty of its use in agricultural settings.
\end{abstract}

$\mathrm{F}$ ECAL BACTERIA concentrations in underlying sediment increase when cattle (Bos taurus) have direct access to streams. These bacteria survive for prolonged periods in stream sediment. Monitoring programs in agricultural watersheds that use indicator bacteria, such as FCs and FS, to assess water quality, may be biased as a result. Since bottom disturbance resuspends fecal bacteria in sediment (Gary and Adams, 1985; Sherer et al., 1988), they may also appear in overlying water for extended periods (Biskie et al., 1988; Jawson et al., 1982; Stephenson and Rychert, 1982). Consequently,

Department of Agronomy, Univ. of Kentucky, Lexington, KY 405460091. Contribution of the Kentucky Agric. Exp. Stn., Lexington, KY. Received 12 June 1995. *Corresponding author (mscoyn00@pop.uky. edu).

Published in J. Environ. Qual. 25: 1216-1220 (1996). streams flowing through pastures typically exceed EPA limits for primary contact water $(200 \mathrm{FCs} / 100 \mathrm{~mL})$ long after cattle are removed (Howell et al., 1995; Jawson et al., 1982; Stephenson and Street, 1978).

Small sediment particle size increases Escherichia coli (FC) survival (Tate, 1978). Extended survival of $E$. coli and Salmonella in sediments with high clay contents has been attributed to organic matter and nutrients held by the clay (Burton et al., 1987) and to physical protection in macropores. Moisture content, $\mathrm{pH}$, sunlight, competition from indigenous soil microflora, and ambient temperature are other environmental factors that affect fecal bacteria survival in soil (Gerba et al., 1975). Higher temperature usually increases bacterial mortality but it can also promote FC regrowth in aquatic environments (Doran and Linn, 1979; Stephenson and Street, 1978).

Howell et al. (1995) noted that the FC/FS ratio increased in streams of central Kentucky as temperature increased during spring. Ideally, the FC/FS ratio could be used to assess whether nonpoint source pollution comes from fecal contamination by humans (FC/FS > 4), domestic animals (FC/FS between 0.1 and 0.6 ), or wild animals ( FC/FS < 0.1) (Geldreich, 1976). However, the ratio has had questionable applicability in agricultural settings (Doran and Linn, 1979; Howell et al., 1995; Jawson et al., 1982) and is no longer recommended to distinguish between human and animal sources of contamination (APHA, 1992). This is due, in part, to the variability of FC/FS ratios.

We were interested in accounting for the variability in $\mathrm{FC} / \mathrm{FS}$ ratios that we have observed on a seasonal basis in agricultural watersheds (Howell et al., 1995). While the individual effect of ambient temperature and particle size on fecal bacteria survival have been studied, the interactive effect of these parameters has not. Furthermore, FC growth shortly after manure deposition may explain some of the variability we have observed in

Abbreviations: EPA, Environmental Protection Agency; FC, fecal coliform; FS, fecal streptococci. 
water-monitoring studies (Howell et al., 1995). Our objectives were to observe whether interactive effects between sediment particle size and temperature influenced fecal bacteria growth and mortality in sediment. We also wanted to demonstrate that these effects, individual and interactive, confound use of the FC/FS ratio as an indicator of fecal contamination sources in agricultural settings.

\section{MATERIALS AND METHODS}

Treatment design for the experiment was a factorial arrangement of four substrates (physiological saline, sand, loam, and clay) and three incubation temperatures $\left(4,25\right.$, and $\left.35^{\circ} \mathrm{C}\right)$. Particle-size distribution in each sediment type was determined by sieving and the hydrometer method (Table 1).

Two hundred and fifty grams of substrate was placed in $500-\mathrm{mL}$ Nalgene bottles and a slurry containing $10 \pm 0.05 \mathrm{~g}$ of fresh cattle manure and $200 \mathrm{~mL}$ of sterile physiological saline $(8.5 \mathrm{~g} \mathrm{NaCl} / \mathrm{L}$ water) was added to each bottle. Sediment were nonsterile but contained no fecal bacteria prior to adding the manure slurry. The mixtures were shaken on a mechanical flatbed shaker for $30 \mathrm{~min}$ to ensure thorough mixing and allowed to settle for $2 \mathrm{~h}$. Fecal coliforms and FS were subsequently enumerated to determine initial concentrations. Each particle size and water treatment was incubated at 4,25 , and $35^{\circ} \mathrm{C}$ for $40 \mathrm{~d}$. All sediment treatments were saturated and maintained at a constant volume by adding sterile physiological saline. The bottle caps were loosened during the incubations to permit air exchange while minimizing evaporation. The experiment was replicated three times with each replicate done in a different 40-d period.

\section{Data Collection}

At $0,3,8,15,20,30$, and $40 \mathrm{~d}, 10$-g subsamples from each bottle were collected with a spatula with minimal disturbance to the sediment. Ten milliliter subsamples of the physiological saline treatment were also collected. Fecal coliforms and FS in each subsample were enumerated by spiral plating after 10 -fold dilution in sterile physiological saline. Fecal coliforms were incubated on $\mathrm{mFC}$ agar (Difco Corp., Detroit, MI) for $22 \pm 2 \mathrm{~h}$ at $44.5^{\circ} \mathrm{C}$. Fecal streptococci were incubated on KFS agar (Difco) for $44 \pm 4 \mathrm{~h}$ at $35^{\circ} \mathrm{C}$. All dark blue colonies growing on mFC agar were counted and assumed to be presumptive FCs. All red and light red colonies growing on KFS agar were counted and assumed to be presumptive FS.

The dry weight of sediment was determined $2 \mathrm{~h}$ after initial mixing and on Day 15 of incubation. The initial dry weight of each sediment was used to calculate the fecal bacteria per gram of dry sediment for the sample at Day 0 . Dry weights determined $15 \mathrm{~d}$ later were used to calculate fecal bacteria populations per gram dry sediment for samples taken from Day 3 to 40 . Since the samples stayed at a constant volume, the percent dry weight of each substrate remained approximately constant after the initial sample. Fecal bacteria in the physiological saline treatment are reported as organisms per milliliter of water.

\section{Statistical Analysis}

Since bacterial counts increased from Day 0 to 3, but decreased thereafter, the data from Day 3 to $\mathbf{4 0}$ were analyzed for differences in bacterial mortality rates. For this analysis, bacterial counts were transformed to the natural logarithm (In) of count +1 . For each experimental unit, the linear regression of $\ln ($ count +1$)$ on number of days incubation was computed
Table 1. Particle-size distribution of coarse, medium, and fine sediment.

\begin{tabular}{lrrrc}
\hline Sediment type & Clay & Silt & Sand & Textural class \\
\hline & & $\%$ & & \\
Coarse & 0 & 0 & 100 & Sand \\
Medium & 10 & 49 & 41 & Loam \\
Fine & 100 & 0 & 0 & Clay \\
\hline
\end{tabular}

as a measure of mortality rate for FCs and FS. Regressions of the difference between FCs and FS with respect to In (count $+1)$ were also computed. Treatment differences with respect to such regressions were evaluated by analysis of variance of the regression coefficients obtained from the individual experimental units.

Bacterial half-lives, that is, the number of days, $X_{50}$, required to reduce culturable cells by $50 \%$ from their maximum concentration (assumed to have occurred on Day 3), were estimated for each treatment using the model

$$
\ln (\text { count }+1)=\beta_{0}+\beta_{1} X^{\beta_{2}}+e
$$

where $\beta_{0}, \beta_{1}$, and $\beta_{2}$ are model parameters to be estimated, $X$ is the number of days after deposition, and $e$ is a random error. Note that Eq. [1] postulates an exponential decay curve of the form $y=\alpha e^{-\gamma z}$ where $a=e^{\beta_{0}}, \gamma=-\beta_{1}$, and $z=$ $X^{\beta_{2}}$. The solution for $X_{50}$ is

$$
X_{50}=\left[\beta_{1}^{-1} \ln 0.5+3^{\beta_{2}}\right]^{1 / \beta_{2}}
$$

Least squares fitting of the nonlinear model, Eq. [1], was accomplished using SAS procedure NLIN (SAS Institute, Inc., 1990). The exponential decay curve would be equivalent to Eq. [1] with $\beta_{2}=1$. To show that Eq. [1] was a better fit, all that was needed was to test $H_{0} / \beta_{2}=1$. Rejection of $H_{0}$ implied that Eq. [1] was more appropriate than the exponential decay curve.

\section{RESULTS AND DISCUSSION \\ Effects of Sediment Type and Temperature on Mortality}

There was no evident interaction between sediment and temperature on fecal coliform $(P=0.659)$ and fecal streptococci $(P=0.243)$ mortality rates. Consequently, for some comparisons, the results were averaged across either all sediment types or all temperature regimes.

Table 2. Fecal coliform and fecal streptococci mortality rates as influenced by substrate type and temperature.

\begin{tabular}{lccc}
\hline Treatment & $\begin{array}{c}\text { Fecal coliform } \\
\text { mortality rate } \\
\text { (FC) }\end{array}$ & $\begin{array}{c}\text { Fecal streptococci } \\
\text { mortality rate } \\
\text { (FS) }\end{array}$ & $\begin{array}{c}\mathrm{H}_{0} / \mathrm{FC}-\mathrm{FS}=0 \text { 怙 } \\
P>|\mathrm{T}|\end{array}$ \\
\hline Substrate & & & \\
Water & $0.128 \mathrm{a}$ & $0.087 \mathrm{a}$ & 0.0004 \\
Sand & $0.104 \mathrm{a}$ & $0.078 \mathrm{ab}$ & 0.0153 \\
Loam & $0.103 \mathrm{a}$ & $0.068 \mathrm{ab}$ & 0.0020 \\
Clay & $0.043 \mathrm{~b}$ & $0.046 \mathrm{~b}$ & 0.7576 \\
Temperature & & & \\
$4^{\circ} \mathrm{C}$ & $0.047 \mathrm{a}$ & $0.018 \mathrm{a}$ & 0.0024 \\
$25^{\circ} \mathrm{C}$ & $0.097 \mathrm{~b}$ & $0.079 \mathrm{~b}$ & 0.0453 \\
$35^{\circ} \mathrm{C}$ & $0.139 \mathrm{c}$ & $0.113 \mathrm{c}$ & 0.0056 \\
\hline
\end{tabular}

$\dagger$ Mortality rates are in units of $\ln$ cells $d^{-1}$. Mortality rates in the same column with the same letters are not significantly different. The effect of substrate on mortality rate is averaged across the three incubation temperatures and the effect of temperature on mortality rate is averaged across each substrate type.

¥ The null hypothesis, Ho, is that fecal coliform (FC) mortality rates are equal to fecal streptococci (FS) mortality rates. 
Table 3. The influence of substrate type and temperature on the mortality rates and half-lives of fecal coliforms and fecal streptococci.

\begin{tabular}{|c|c|c|c|c|c|}
\hline \multirow[b]{2}{*}{$\begin{array}{l}\text { Substrate } \\
\text { type }\end{array}$} & \multirow[b]{2}{*}{$\begin{array}{c}\text { Temperature, } \\
{ }^{\circ} \mathrm{C} \\
\end{array}$} & \multicolumn{2}{|c|}{ Fecal coliforms } & \multicolumn{2}{|c|}{ Fecal streptococci } \\
\hline & & $\begin{array}{l}\text { Mortality } \\
\text { rate† }\end{array}$ & $\begin{array}{l}\text { Half-life, } \\
\text { d }\end{array}$ & $\begin{array}{l}\text { Mortality } \\
\text { rate }\end{array}$ & $\begin{array}{c}\text { Half-life, } \\
\text { d }\end{array}$ \\
\hline Water & $\begin{array}{r}4 \\
25 \\
35\end{array}$ & $\begin{array}{l}0.077 \mathrm{abc} \\
0.135 \mathrm{cde} \\
0.172 \mathrm{e}\end{array}$ & $\begin{array}{r}15.6 \\
13.9 \\
4.3\end{array}$ & $\begin{array}{l}0.029 a \\
0.109 a \\
0.124 b c\end{array}$ & $\begin{array}{r}35.9 \\
6.4 \\
4.4\end{array}$ \\
\hline Sand & $\begin{array}{r}4 \\
25 \\
35\end{array}$ & $\begin{array}{l}0.043 \mathrm{ab} \\
0.124 \mathrm{cde} \\
0.146 \mathrm{de}\end{array}$ & $\begin{array}{r}13.1 \\
7.3 \\
4.2\end{array}$ & $\begin{array}{l}0.013 a \\
0.119 b c \\
0.103 b c\end{array}$ & $\begin{array}{r}41.5 \\
5.4 \\
4.6\end{array}$ \\
\hline Loam & $\begin{array}{r}4 \\
25 \\
35\end{array}$ & $\begin{array}{l}0.043 a b \\
0.108 b c d e \\
0.156 \mathrm{e}\end{array}$ & $\begin{array}{r}18.1 \\
15.7 \\
4.3\end{array}$ & $\begin{array}{l}0.010 a \\
0.064 a b \\
0.130 c\end{array}$ & $\begin{array}{r}40.6 \\
11.5 \\
6.2\end{array}$ \\
\hline Clay & $\begin{array}{r}4 \\
25 \\
35\end{array}$ & $\begin{array}{l}0.025 a \\
0.022 a \\
0.083 a b c d\end{array}$ & $\begin{array}{r}24.7 \\
36.9 \\
6.4\end{array}$ & $\begin{array}{l}0.019 a \\
0.025 a \\
0.095 b c\end{array}$ & $\begin{array}{r}39.1 \\
31.9 \\
9.3\end{array}$ \\
\hline
\end{tabular}

$\dagger$ Mortality rates are in units of $\ln$ cells $\mathrm{d}^{-1}$. Mortality rates in the same column followed by the same letters are not significantly different.

Overall, sediment type significantly affected fecal coliform mortality $(P=0.001)$ but not FS mortality $(P=$ $0.131)$. Fecal coliform mortality rates were significantly less in clay-sized sediment than in coarser sediment or physiological saline (Table 2). Fecal streptococci mortality rates were also significantly less in clay-sized sediment than in physiological saline but not significantly less than in other sediment types (Table 2). Sherer et al. (1992) also observed that FCs survived longer in fine sediments than in coarse sediments and found no differences in FS survival between fine and coarse sediments. Grimes (1980) suggested that higher FC populations in clayey sediments are the result of surface area and particlecharge differences.

Fecal coliforms survive longer in sediment-laden than sediment-free water (Sherer et al., 1992). In our study, FC and FS mortality rates were higher in physiological saline than in other treatments, but this difference was not significant when compared to sediment types other than clay (Table 2). Bacterial survival in physiological saline may have been affected by particulates in the manure. In effect, the particulates provided a range of particle sizes on which the fecal bacteria could attach and grow.

Temperature significantly affected both FC and FS mortality $(P=0.001)$. As temperature increased, mortality rates significantly increased (Table 2 ). Other studies have shown that temperature affects fecal bacteria survival in water, soil, and sediment (Faust, 1982; Gerba et al., 1975; Von Donsel et al. 1967; Zibilske and Weaver, 1978). Salmonella typhimurium mortality in soil, for example, increases with increasing temperature (Zibilske and Weaver, 1978).

We calculated bacterial half-lives using nonlinear models because mortality was not predicted well by simple exponential decay $\left[\ln \left(N / N_{\mathrm{o}}\right)=-k t\right]$ (Table 3). As temperature increased or as sediments became coarser, fecal bacteria mortality became increasingly nonlinear (Fig. 1). Davies et al. (1995) also reported that simple exponential decay did not accurately reflect the mortality of fecal bacteria in freshwater and marine sediments. They attributed this to complications because of predation and growth. These are also potential explanations for our
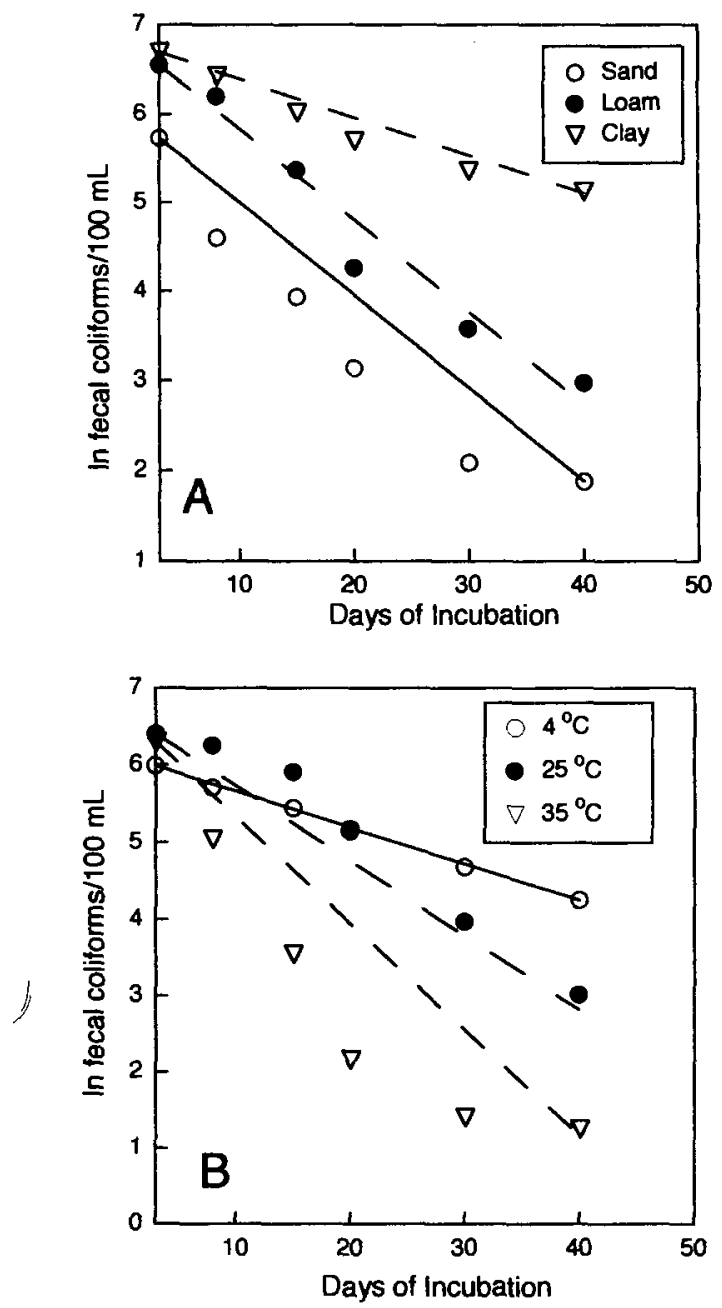

Fig. 1. Nonlinear mortality of fecal coliforms in sediment of various particle size $(A)$ or at different temperature $(B)$. Symbols represent the mean concentration of FCs averaged across temperature $(A)$ or particle size $(B)$, respectively. The plotted regression lines are the predicted exponential decay using a simple first-order model with rate constants derived from Table 2.

system since predators, such as protozoa, were not excluded from the manure used in the study and conditions were favorable for bacterial growth at the higher incubation temperatures.

Our data reflect culturable rather than total viable cells. This underestimates the true half-life of the fecal bacteria since the initial population is underestimated. We assume that it does not affect the mortality rates unless viable but nonculturable bacteria differ in this respect. Davies et al. (1995) reported a study in which the proportion of culturable to viable but nonculturable $E$. coli remained constant. So, the culturable cells in our study are probably a reasonable indicator of overall FC mortality rates. In the absence of information to the contrary, we assume the same is also true for FS, though this clearly may not be valid.

\section{Fecal Coliform Mortality vs. Fecal Streptococci Mortality}

Fecal streptococci mortality rates were significantly less than FC mortality rates in physiological saline, sand, and loam but the mortality rates of both fecal bacteria 

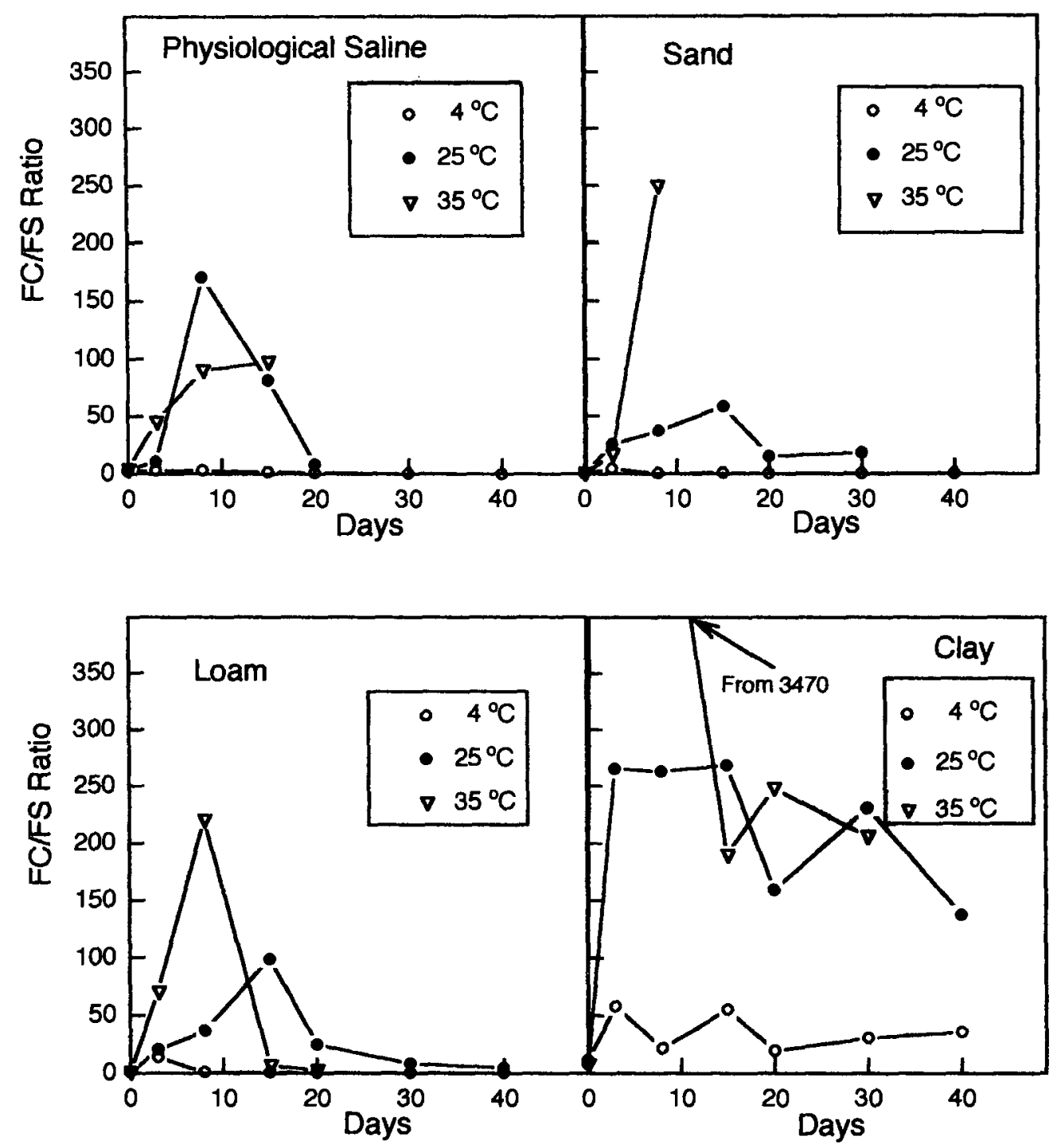

Fig. 2. Effect of sediment type and incubation conditions on the fecal coliform/fecal streptococci (FC/FS) ratio of cattle manure-amended sediment.

were similar in clay (Table 2). This is in contrast with observations by Sherer et al. (1992) that FS survive longer than FCs in fine sediment and FCs survive longer in coarse sediment. Fecal coliform survival was also significantly less than FS survival at each incubation temperature in our study (Table 2).

Fecal streptococci mortality rates were less than FC mortality rates for all treatment combinations except for clay-sized particles at 25 and $35^{\circ} \mathrm{C}$ (Table 3). Although FS mortality rates were lower for most treatment combinations, FC half-lives exceeded FS half-lives at $25^{\circ} \mathrm{C}$ and were approximately equal at $35^{\circ} \mathrm{C}$ in all substrates but clay (Table 3 ).

Fecal coliform concentrations increased until Day 3 of incubation (data not shown). After $3 \mathrm{~d}$ incubation at 25 and $35^{\circ} \mathrm{C}$, FCs greatly exceeded FS. This caused greater FC half-lives even though their mortality rates were higher than that of FS. Because death is a rate process, and is independent of the actual number of organisms, the higher the initial number of organisms, the longer the apparent survival (Von Donsel et al., 1967).

Fecal coliform regrowth in soil, sediment, and runoff water has frequently been reported (Crane et al., 1980; Doran and Linn, 1979; Von Donsel, 1967). Doran and Linn (1979) noted that FS concentration in runoff water containing fresh cattle feces changed little over a 40-h incubation at 4 and $21^{\circ} \mathrm{C}$. However, while $S$. bovis initially made up $81 \%$ of the FS population, after a $40-\mathrm{h}$ incubation at 4 and $21^{\circ} \mathrm{C}, S$. bovis made up 19 and $1 \%$ of the population, respectively. They suggested that while the $S$. bovis population declined during incubation, nonstarch hydrolyzing FS increased to maintain a constant FS population.

\section{Fecal Coliform/Fecal Streptococci Ratio}

On Day 0 , all $\mathrm{FC} / \mathrm{FS}$ ratios were indicative of the domestic animal source of feces except in the clay substrate where the ratio exceeded 7 . The high ratio in the clay substrate may be caused by different adsorption characteristics of FCs and FS (Biskie et al., 1988). Bacterial cell surface hydrophobicity influences adhesion of bacteria to solid surfaces and streptococci have been found with greater hydrophobicity than $E$. coli (Huysman and Verstraete, 1993). The greater hydrophobicity of 
FS may increase their adherence to clay. Consequently, on Day 0 and thereafter, fewer FS than FCs would be extracted from clay during enumeration and this could contribute to an elevated FC/FS ratio.

At $4^{\circ} \mathrm{C}$, the $\mathrm{FC} / \mathrm{FS}$ ratio remained between 0.1 and 4, except when the sediment was clay sized (Fig. 2). The low temperature may have impeded FC regrowth and slowed $S$. bovis mortality, thereby maintaining a ratio indicative of contamination by cattle. At 25 and $35^{\circ} \mathrm{C}$, the $\mathrm{FC} / \mathrm{FS}$ ratio almost always exceeded 4 even though FC mortality rates exceeded FS mortality rates. This was caused by the elevated FC concentrations after $3 \mathrm{~d}$ of incubation. Doran and Linn (1979) found the FC/ FS ratio of runoff water containing fresh bovine feces increased from approximately 1 to 315 within $40 \mathrm{~h}$ at $21^{\circ} \mathrm{C}$. This was attributed to a 330 -fold increase of FCs while FS counts remained constant.

\section{CONCLUSIONS}

Our study indicates, as have other reports, that fecal bacteria have prolonged survival in sediment. Under controlled conditions, in which physiological saline was used to reduce cell death by osmotic shock, FC mortality rates were higher than FS mortality rates. These rates decreased as sediment particle size became finer and as temperature decreased, but there was no evidence for interaction between these two factors in determining fecal bacteria persistence. The apparent half-lives of fecal coliforms exceeded those of FS, even though mortality rates were higher, because of FC regrowth shortly after deposition.

The FC/FS ratio is influenced by temperature, the presence of sediment, and sediment particle size. During warmer weather, FC regrowth increases FC/FS ratios to levels indicative of human contamination even where none clearly exists. These factors interfere with the interpretation of the FC/FS ratio and contribute to the difficulty of its use in agricultural settings.

\section{ACKNOWLEDGMENTS}

This work was supported by a grant from the State of Kentucky Senate Bill 271 Water Quality Research Program.

\section{REFERENCES}

American Public Health Association. 1992. Standard methods for the examination of water and waste water. 18th ed. Am. Public Health Assoc., Washington, DC.
Biskie, H.A., B.M. Sherer, and J.A. Moore. 1988. Fate of organisms from manure point loading into rangeland stream. ASAE Paper 88-2081. ASAE, St. Joseph, MI.

Burton, G.A., D. Gunnison, and G.R. Lanza. 1987. Survival of pathogenic bacteria in various freshwater sediments. Appl. Environ. Microbiol. 53:633-638.

Crane, S.R., P.W. Westerman, and M.R. Overcash. 1980. Die-off of fecal indicator organisms following land application of poultry manure. J. Environ. Qual. 9:531-537.

Davies, C.M., J.A.H. Long, M. Donald, and N.J. Ashbolt. 1995. Survival of fecal microorganisms in marine and freshwater sediment. Appl. Environ. Microbiol. 61:1888-1896.

Doran, J.E., and D.M. Linn. 1979. Bacteriological quality of runoff water from pastureland. Appl. Environ. Microbiol. 37:985-991.

Faust, M.A. 1982. Relationship between land-use practices and fecal bacteria in soil. J. Environ. Qual. 11:141-146.

Gary, H.L., and J.C. Adams. 1985. Indicator bacteria in water and stream sediments near the snowy range in southern Wyoming. Water, Air, Soil Pollut. 25:133-144.

Geldreich, E.E. 1976. Fecal coliform and fecal streptococcus density relationships in waste discharges and receiving waters. Crit. Rev. Environ. Control 6:349-369.

Gerba, C., C. Wallis, and J. Mellnick. 1975. Fate of wastewater bacteria and viruses in soil. J. Irrig. Drain. 101:157-174.

Grimes, D.J. 1980. Bacteriological water quality effects of hydraulically dredging contaminated upper Mississippi river bottom sediment. Appl. Environ. Microbiol. 39:782-789.

Howell, J.M., M.S. Coyne, and P.L. Cornelius. 1995. Fecal bacteria in agricultural waters of the bluegrass region of Kentucky. J. Environ. Qual. 24:411-419.

Huysman, F., and W. Verstraete. 1993. Water-facilitated transport of bacteria in unsaturated soil columns: Influence of inoculation and irrigation methods. Soil Biol. Biochem. 25:91-97.

Jawson, M.D., L.F. Elliott, K.E. Saxton, and D.H. Fortier. 1982. The effect of cattle grazing on indicator bacteria in runoff from a Pacific northwest watershed. J. Environ. Qual. 11:621-627.

SAS Institute, Inc. 1990. SAS/STAT users guide. Version 6, 4th ed., Vol. 2. SAS Inst., Inc., Cary, NC.

Sherer, B.M., J.R. Miner, J.A. Moore, and J.C. Buckhouse. 1988. Resuspending organisms from a rangeland stream bottom. Trans. ASAE 31:1217-1222.

Sherer, B.M., J.R. Miner, J.A. Moore, and J.C. Buckhouse. 1992. Indicator bacterial survival in stream sediments. J. Environ. Qual. 21:591-595.

Stephenson, G.R., and R.C. Rychert. 1982. Bottom sediment: A reservoir of Escherichia coli in rangeland streams. J. Range Manage. 35:119-123.

Stephenson, G.R., and L.U. Street. 1978. Bacterial variations in streams from a southwest Idaho rangeland watershed. J. Environ. Qual. 7:150-157.

Tate, R.L., III. 1978. Cultural and environmental factors affecting the longevity of Escherichia coli in histosols. Appl. Environ. Microbiol. 35:925-929.

Von Donsel, D., E. Geldreich, and H. Clark. 1967. Seasonal variations in the survival of indicator bacteria in soil and their contribution to storm water pollution. Appl. Microbiol. 5:1362-1370.

Zibilske, L.M., and R.W. Weaver. 1978. Effect of environmental factors on survival of Salmonella typhimurium in soil. J. Environ. Qual. 7:593-597. 